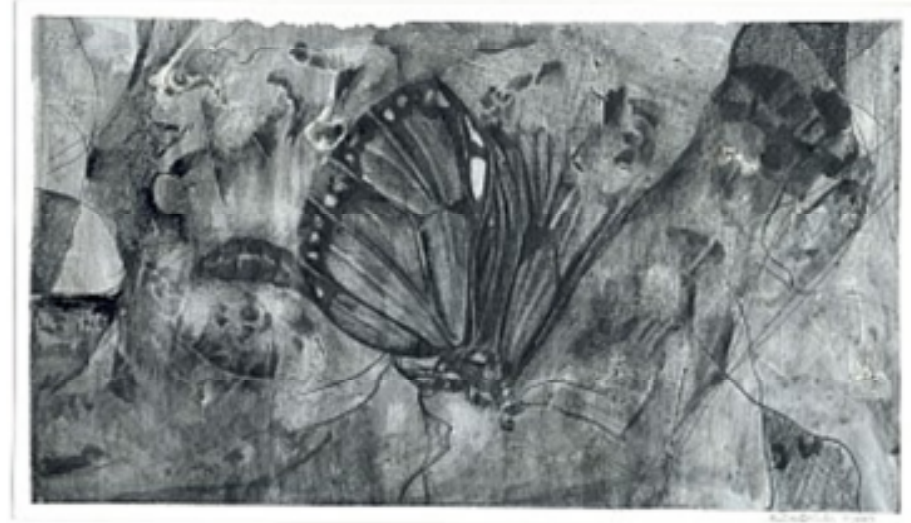

Ilustração Kátia Batista

\title{
Metade da minha obra completa
}

\section{Bruno Brum}

Bruno Brum é poeta e artista gráfico. Publicou em 2004 seu primeiro livro, mínima idéia, pela Selo Editorial. É editor da Revista de Autofagia e do blog saborgraxa.blogspot.com.

metade da minha obra completa

pula do topo da gaveta

enquanto um outro tanto

um quinto, talvez, completa hoje

seu terceiro aniversário

(algo em torno

de 1095 dias)

ao passo que uma outra

metade está agora na rua

e esbarra em dois terços

da segunda parte sem

que ninguém perceba 
Txt: Leituras Transdisciplinares de Telas e Textos, Belo Horizonte, v.1, n.2, p.77-78, 2005

nem mesmo aquela metade

que pulou da gaveta

e que agora coça uma pereba

no canto do cotovelo

a segunda metade, composta

de quintos, terços, sextos

não catalogados

se espreguiça na janela

do seu quarto

enquanto cada parte

perde o que lhe cabe

entre tantas outras

que se extinguem antes

que tudo se acabe 